\title{
Nest construction and architecture of the Amazonian bumble bee (Hymenoptera: Apidae)
}

\author{
Olivia Mariko TAYLOR ${ }^{\mathrm{a}}$, Sydney A. CAMERON ${ }^{\mathrm{b} *}$ \\ a Department of Biology, University of Victoria, PO Box 1700 STN CSC Victoria, BC, V8W 2Y2 Canada \\ b Department of Entomology, University of Illinois, Urbana-Champaign, 320 Morrill Hall, 505 S. Goodwin Ave., \\ Urbana, IL 61801, USA
}

(Received 8 February 2002; revised and accepted 1 November 2002)

\begin{abstract}
The Amazonian bumble bee, Bombus transversalis, is mostly restricted to tropical rain forest of the Amazon Basin. Little is known of its biology, in part because its surface nests are cryptic and hard to find. Here we examine nest site characteristics, nest architecture and construction behavior from 16 colonies observed in different regions of Amazonia. We quantify structural features of the nest habitat and external and internal characteristics of the nests. We ascertain that nests are constructed on terra firme, on the surface of the ground and incorporate elements of growing vegetation as physical support. Nests consist of a thatched canopy of tightly woven leaves and rootlets, beneath which lies the brood and food storage pots. To build the nest, workers cut and transport leaves from the surrounding forest floor. Nests are dry inside, despite torrential rainfall and external relative humidity levels near $100 \%$. Nests may be reused although a colony appears to persist for only one season.
\end{abstract}

corbiculate bees / Bombus transversalis / neotropics / leaf-cutting behavior / adaptation / colony life cycle

\section{INTRODUCTION}

In the family Apidae (sensu Roig-Alsina and Michener, 1993), the bumble bees (Bombus Latreille) comprise a group of approximately 240 eusocial species (Williams, 1998). They are most diversified and abundant in the temperate higher elevations and cool, mesic regions of the Northern Hemisphere (Plowright and Laverty, 1984; Labougle, 1990), where they commonly nest below ground in abandoned rodent burrows (Sakagami, 1976). Within South America, bumble bees are more numerous at moderate to high altitudes in the mountains and in the subtropical and temperate southern portions of the continent, and are taxonomically inconspicuous among tropical lowland fauna
(Michener, 1974). However, the Amazonian bumble bee, Bombus transversalis (Olivier) (subgenus Fervidobombus), is unusual in being mostly restricted to tropical lowland rain forests of the Amazon Basin (Lievano et al., 1991; Cameron et al., 1999), where permanently humid climate, appropriate nesting sites and intense predation present major challenges to most ground nesting bees, including bumble bees (Janzen, 1971; Michener, 2000; Cameron et al., 1999; Ramírez and Cameron, in press). As is true of most Fervidobombus (Cameron and Williams, 2003), B. transversalis nests on the surface of the ground, yet this species found a way to survive the exigencies of living on the forest floor in tropical rain forest, which is often partially flooded. What features might have been selected or enhanced as

\footnotetext{
* Correspondence and reprints

E-mail: scameron@life.uiuc.edu
} 


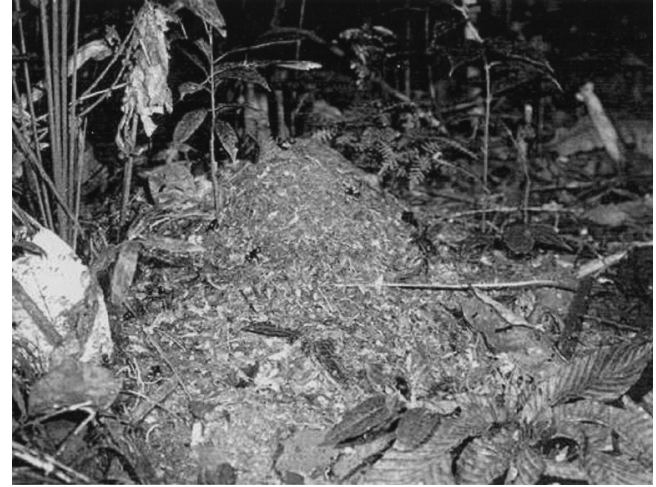

Figure 1. Bombus transversalis nest illustrating the conical shape, canopy characteristics and physical support protruding through the nest (modified from Cameron et al., 1999).

$B$ transversalis moved into rain forest habitat from surrounding temperate areas? Published reports on colonies discovered in the wild all mention the unique composition of the nest, which resembles a pile of thatched leaves (Fig. 1). Thus nesting biology seems a promising avenue from which to begin an examination of potential adaptations enabling $B$. transversalis to survive in the wet tropics.

Nests have been described for a number of Neotropical Fervidobombus species (Tab. I), but detailed descriptions of nest site characteristics and nest architecture are wanting for B. transversalis (and many of the other Fervidobombus species). Four published accounts have reported on only three nests (Dias, 1958; Olesen, 1989; Cameron and Whitfield, 1996; Cameron et al., 1999), precluding comparative insights and a full understanding of their nesting biology. In this report we describe characteristics of the nest sites and nest architecture from 16 colonies of $B$. transversalis studied at five sites within Amazonian Colombia, Brazil, Ecuador and Peru. We focus on physiographic and topological features of nesting sites and provide a detailed description of the nest

Table I. Nesting sites described for tropical species of Bombus within the subgenus Fervidobombus (Burks, 1951; Krombein, 1967; Sakagami, 1976). Regions where the species are thought to occur (documented by Williams, 1998) are shown in italics.

\begin{tabular}{|c|c|c|c|c|}
\hline $\begin{array}{l}\text { Species of } \\
\text { Bombus }\end{array}$ & Areas observed & Habitat & Nest site preference & Author(s) \\
\hline $\begin{array}{l}\text { atratus } \\
\text { Franklin }\end{array}$ & $\begin{array}{l}\text { South America } \\
\text { (Brazil) } \\
\text { regions: } W, E, S \\
\text { Neotropical }\end{array}$ & $\begin{array}{l}\text { Tropical rain } \\
\text { forest - highlands } \\
\text { and lowlands }\end{array}$ & $\begin{array}{l}\text { Principally surface } \\
\text { nesters (arboreal and } \\
\text { below ground nests } \\
\text { found) }\end{array}$ & $\begin{array}{l}\text { Dias, 1960; Sakagami } \\
\text { et al., 1967; Zucchi, 1973; } \\
\text { Lievano et al., 1991; } \\
\text { Cameron and Jost, } 1998\end{array}$ \\
\hline $\begin{array}{l}\text { brasiliensis } \\
\text { Lepeletier }\end{array}$ & $\begin{array}{l}\text { South America } \\
\text { regions: } E \\
\text { Neotropical }\end{array}$ & $\begin{array}{l}\text { Tropical rain } \\
\text { forest - lowlands }\end{array}$ & Semi-subterranean & $\begin{array}{l}\text { Moure and Sakagami, } \\
1962\end{array}$ \\
\hline $\begin{array}{l}\text { medius } \\
\text { Cresson }\end{array}$ & $\begin{array}{l}\text { North America } \\
\text { (Mexico) } \\
\text { regions: S Nearctic } \\
\text { and N Neotropical }\end{array}$ & $\begin{array}{l}\text { Tropical evergreen } \\
\text { forest }\end{array}$ & $\begin{array}{l}\text { Principally surface } \\
\text { nesters (below ground } \\
\text { nests found) }\end{array}$ & $\begin{array}{l}\text { Michener and LaBerge, } \\
\text { 1954; Sakagami et al., } \\
1967\end{array}$ \\
\hline $\begin{array}{l}\text { morio } \\
\text { (Swederus) }\end{array}$ & $\begin{array}{l}\text { South America } \\
\text { (Brazil) } \\
\text { regions: } W, E \\
\text { Neotropical }\end{array}$ & $\begin{array}{l}\text { Tropical rain } \\
\text { forest - mid-lands }\end{array}$ & $\begin{array}{l}\text { Principally surface } \\
\text { nesters (below ground } \\
\text { nests found) }\end{array}$ & $\begin{array}{l}\text { Milliron, 1961; Zucchi, } \\
1973\end{array}$ \\
\hline $\begin{array}{l}\text { pullatus } \\
\text { Franklin }\end{array}$ & $\begin{array}{l}\text { Costa Rica } \\
\text { regions: } N, W \\
\text { Neotropical }\end{array}$ & $\begin{array}{l}\text { Tropical rain } \\
\text { forest - wet lowlands } \\
\text { and highlands }\end{array}$ & $\begin{array}{l}\text { Principally surface } \\
\text { nesters (arboreal nests } \\
\text { found) }\end{array}$ & $\begin{array}{l}\text { Janzen, 1971; Lievano } \\
\text { et al., } 1991\end{array}$ \\
\hline $\begin{array}{l}\text { transversalis } \\
\text { (Olivier) }\end{array}$ & $\begin{array}{l}\text { South America } \\
\text { (Brazil) } \\
\text { regions: } W, E \\
\text { Neotropical }\end{array}$ & $\begin{array}{l}\text { Tropical rain forest - } \\
\text { wet lowlands }\end{array}$ & Surface nesters & $\begin{array}{l}\text { Dias, 1958; Olesen, 1989; } \\
\text { Lievano et al., 1991; } \\
\text { Cameron et al., } 1999\end{array}$ \\
\hline
\end{tabular}


architecture summarized from the collective colonies. We also describe the means by which workers construct nests and modify the forest floor in the nest vicinity by clearing patches bare of leaf litter. We conclude that the unusual nest structure is a critical factor in the successful survival of $B$. transversalis in the rain forest.

\section{MATERIALS AND METHODS}

Field colonies of B. transversalis were examined at five locations: Colombia (Amacayacu National Park, along the Amazon river [03ㅇำ $49^{\prime} \mathrm{S}, 70^{\circ} 15^{\prime} \mathrm{W}$ ], May 17-19, May 25-June 12, 2000); Brazil (Palmarí Reserve along the Javarí River [04'50'S, k70 01'47'W], May 20-24, 2000); Ecuador (Tiputini Biodiversity Station [University of San Francisco, Quito] along the Tiputini River [00 38'18’'S, 76 09'W], June 17-26, 2000 and Yasuní Scientific Research Station, near the Tiputini River, Orellana $\left[00^{\circ} 05^{\prime} \mathrm{S}, 75^{\circ} 47^{\prime} \mathrm{W}\right.$ ], June 26-July 7, 2000); and, Peru (Tambopata-Candamo Reserve in the state of Madre de Dios [12 $49^{\circ} \mathrm{S}$, $\left.69^{\circ} 24^{\prime} \mathrm{W}\right]$, August 9-22, 2000). All sites were located in rain forest of the Amazon Basin. We collected habitat measurements and nest architectural data from 12 active nests (Tab. II). Nine of the 12 active nests were dissected (see below) and left intact in the field, one was excavated and taken to an indoor laboratory, and two were left undissected in the field. Limited data were collected from an additional four nests that were found vacant, without brood.

Five features of the nest site were measured: (1) relative amounts of vegetation overhanging the nest; (2) degree of shade; (3) directional aspect of the nest; (4) ground slope; and (5) presence or absence of plant structures (roots, saplings, tree buttresses) providing physical support for the nest. The overhanging vegetation included small shrubs and saplings, understory trees, the general forest canopy layer, and emergent trees. Shade was classified into five ranks based on pre-established categories of the number of vegetation layers overhanging the nest: $1=$ complete sun exposure, no shade; $2=$ high sun exposure (limited shade provided throughout the day); $3=$ even mixture of shade cover and sun exposure; $4=$ mostly shaded (limited sun exposure throughout the day); and $5=$ complete shade cover, no direct exposure to sun due to thick canopy coverage. The direction of the nest entrance was taken with a compass bearing. Downward slope was calculated as depicted in Figure 2.

Nest architecture was characterized by size (height, width, length, thickness) of the nest cover

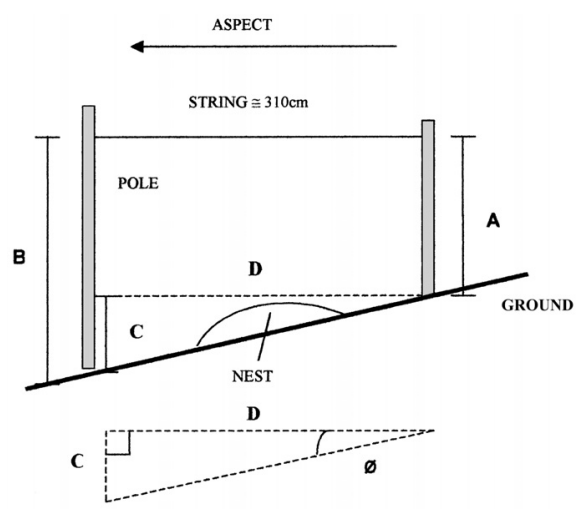

Figure 2. A graphical representation of the measurement of ground slope. Two poles placed vertically into ground on up and down slopes are separated by a taught $310 \mathrm{~cm}$ string. Vertical distance from horizontal string to ground was measured at both poles $(\mathrm{A}, \mathrm{B})$ and the difference between them was used as the vertical measurement (C) for the angle. String length gave the horizontal measurement (D). The degree of slope was calculated as the tangent. Slope direction (aspect) was taken as the down-slope direction.

(canopy) encasing the brood comb, the materials used to construct the canopy, including its internal layers. Colony construction activities and the clearing of patches on the forest floor were observed and recorded with video camera (Canon GL-1) and focal observations of marked individuals during 20-min periods each hour through the day.

Colony size (adult and brood population) was estimated by counting the number of adult bees collected at the nest (excluding absent foragers) and the number of different brood cells (pupae, larval clusters and egg cells). Each larval cluster was estimated to contain an average of six larvae per cluster and each egg cell was estimated to contain five eggs per cell. These estimations were based on multiple observations of brood from colonies in different locations.

Colony dissections were performed by teasing open the nest canopy from the top center after the bees were collected with aerial nets and kept cool in an iced container. Dissections were conducted so as to minimize time of disturbance of the nest structure and brood. To complete a dissection of large nests swiftly, with minimum exposure of brood to the humid ambient air, only half the brood comb was measured for size and half the cells tallied. The dimensions and counts were doubled to obtain total size.

External ambient and internal nest temperatures were recorded with a standard mercury 


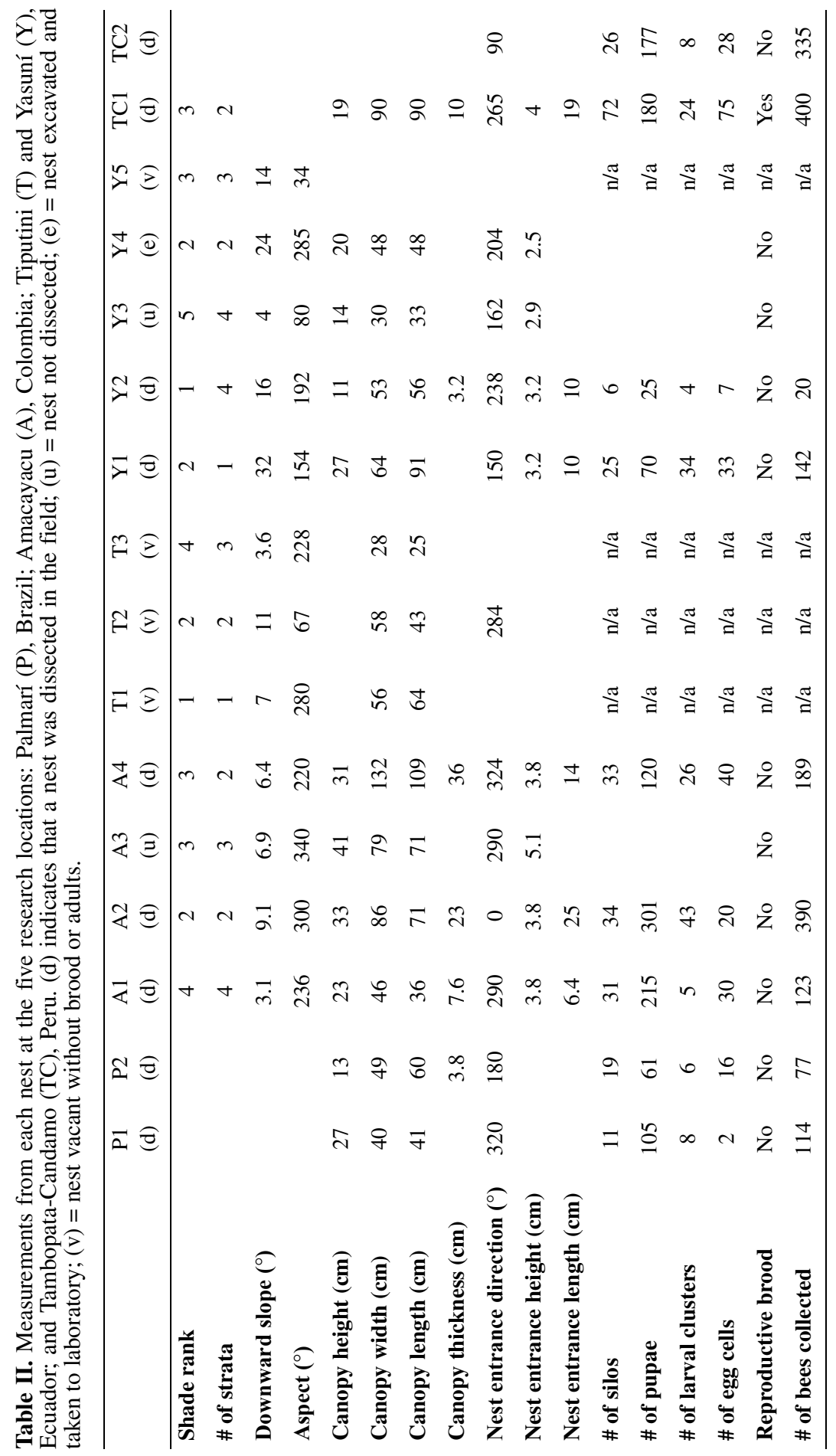


thermometer and HOBO Temperature Logger (Onset Computer Corp.: model \#H01-001-01) placed directly inside the nest through the top of the canopy. Ambient relative humidity was taken with a sling cychrometer. Comparative measurements taken from each nest are tabulated in Table II.

Statistical analyses were implemented in SPSS (vers. 10.0) and JMP IN (vers. 4.0.3). Correlation analysis was used to test for associations between shade rank, vegetational strata, slope and directional aspect of the nest. To assess directional trends in nest entrance orientation, variance of the recorded samples was compared with randomly selected sample variances of compass directions. A paired t-test was used to assess significant differences between internal and external nest temperatures.

\section{RESULTS}

\subsection{Nest site}

All colonies were situated on terra firme. The forest floor at each nest site $(n=16$ : four from Colombia, eight from Ecuador, two from Peru, two from Brazil) was soft and spongy around the nest and rich in detritus (decaying logs, sticks, roots, leaves). There was an abundance of old and a few newly fallen leaves from the surrounding vegetation. Trees, shrubs and undergrowth surrounded most of the nests; only one (P2, Tab. II) was found in a recently logged area and a second (Y4) had no canopy trees directly over the nest. Each colony was situated in a shallow depression on the forest floor, camouflaged by the nest canopy, described below (Nest Architecture). Thirteen of the 16 measured nests used some form of physical support, built either near or against tree buttresses, with variously sized roots intertwined through the canopy $(n=6)$, or constructed around live shrubs or saplings, which extended through the top of the canopy $(\mathrm{n}=7)$.

Shade level varied among 13 ranked nests, with rankings of $2(n=4), 3(n=4)$ and $4(n=$ 2 ). There were variable amounts of overhanging vegetation at nests, from one layer $(n=2)$ to those with two $(\mathrm{n}=5)$, three $(\mathrm{n}=3)$ and four layers $(\mathrm{n}=3)$. No nests were completely exposed to full sun or entirely shaded. Of the nests examined for slope angle of the nest site $(\mathrm{n}=12)$, seven were constructed on slopes inclined at angles from $0^{\circ}$ and $9.9^{\circ}$; the
Table III. Correlation matrix for shade rank, number of strata, angle of slope and aspect of study nest sites $(\mathrm{n}=12)$. Values above the diagonal are $P$-values (2-tailed) and values below are Pearson Correlation coefficients. None of the correlations are statistically significant.

\begin{tabular}{lcccc}
\hline & $\begin{array}{c}\text { Shade } \\
\text { rank }\end{array}$ & Strata & $\begin{array}{c}\text { Slope } \\
\text { angle }\end{array}$ & Aspect \\
\hline Shade rank & & 0.054 & 0.085 & 0.453 \\
Strata & 0.568 & & 0.145 & 0.552 \\
Slope angle & -0.517 & -0.447 & & 0.686 \\
Aspect & -0.240 & -0.191 & -0.130 & \\
\hline
\end{tabular}

remaining five nests were constructed on slopes ranging from $10^{\circ}-39.9^{\circ}$. Nest aspect covered the gamut of compass directions from $0^{\circ}-360^{\circ}$. There are no statistically significant correlations (Tab. III) between any of the four selected habitat variables (shade rank, number of strata above nest, slope and aspect). Thus there is no evidence that $B$. transversalis prefers particular combinations of those nest site variables.

\subsection{Nest architecture}

\subsubsection{Canopy design and construction}

All B. transversalis nests were conical or dome-like in shape (Fig. 1), although one was flatter in appearance with greatly exaggerated dimensions (A4, Tab. II). Canopy width was strongly correlated with canopy length $(P<$ $\left.0.001 ; \mathrm{R}^{2}=0.79\right)$. The structure consists primarily of small fragments of cut leaves, giving the impression of a pile of thatched debris. All nests were cryptic and hard to distinguish from the surrounding ground litter and live vegetation. Canopy thickness ranged from $3-36 \mathrm{~cm}(\mathrm{n}=6$; mean $=13.8 \mathrm{~cm})$, with varying numbers of distinguishable layers. The outermost layer was damp from rain and high humidity, and was composed of fine, small pieces of leaves, rootlets and root hairs. The subsequent layers descending toward the interior of the nest were normally completely dry and arranged in sheets, often with whole leaves layered together. Beneath the thick canopy, an air space $(2.5-7.5 \mathrm{~cm}$ in height) separated the inner canopy wall from the brood. Although healthy nests were entirely 
dry beneath the first few centimeters of the outer canopy layer, weaker nests (old queen, not much developing brood) were damp throughout and contained fungus within the canopy layers.

All nests had a single entrance, the height of which is correlated with the height of the canopy $\left(P=0.026 ; \mathrm{R}^{2}=0.53\right)$. Nest entrances were not closed or visibly camouflaged, and were located at, or slightly above, ground level, flush with the nest canopy. Entrances are, however, cryptic and the easiest way to distinguish them from the rest of the canopy is to watch for entering and exiting bees. Location of nest entrances was not significantly biased in any given compass direction $(\mathrm{n}=13$; $P>0.20)$.

\subsubsection{Leaf collection}

Observations of marked workers engaged in nest construction activities indicated a degree of task specialization. Workers tagged from colonies A3, Y3, TC1 and TC2 (Tab. II) while sweeping and cutting leaves near or on the nest canopy remained constant to those tasks for several days or more. Their activities during the day were limited to building and maintaining the nest thatching, and included the cutting of whole leaves into small pieces (approx. 2-4 $\mathrm{cm} \times 1 \mathrm{~cm}$ ) with the mandibles and the transport of the leaf fragments onto the canopy from the forest floor. Workers transferred the leaf fragments to the nest by dragging or sweeping the pieces backwards as they moved forward. Often in tandem, workers would push and scrape leaves backwards beneath the body, with one individual sweeping the fragments back to an individual behind, who would in turn sweep the leaf material rearward to the next individual. As many as five individuals were seen together moving leaves in this fashion at the Y3 nest. This cooperative effort was usually not continuous, as individuals frequently interrupted leaf-cutting or sweeping with short flights or walks back to the canopy. More often, a leaf was transferred by only one individual or two working some of the time in tandem. Ultimately, leaves and rootlets were moved from the forest floor to the nest and likewise spread evenly over the canopy. The canopy itself undergoes constant maintenance by the sweeping and scraping motions of the workers. Leaves selected for cutting are older (dark and dry); rarely did workers cut pieces of freshly fallen green leaves. The bees do not use the vein and stem regions of leaves, which are left lying on the forest floor.

\subsubsection{Clearings on the forest floor}

Throughout the geographic range of this study, none of the colonies possessed linear ground trails (discernible by an absence of vegetation along a linear trajectory from the nest), such as those observed by Cameron et al. (1999) for a colony in Peru. Instead, clearings were present as patches around the periphery of the nest. Yet, as described in Cameron et al. (1999), individuals were frequently seen following one another in tandem along stretches of the nest canopy and along specific areas on the forest floor. For instance, a marked worker from colony A3, with relatively few canopy-construction bees visible on the outside, traveled the same pathway (among several) for at least six days, walking along a buttress leading out from behind the nest. This bee walked back and forth along the route (up to $2 \mathrm{~m}$ in distance) to and from the canopy, sometimes stopping to chew on a leaf along the path, returning repeatedly to the same leaf before a piece was cut. The leaf-cutting activity of colony Y4, a young colony $(<1$ month) in the early stages of development (Tab. II), resulted in the clearing of what initially appeared to be a linear trail leading a short distance away from one side of the nest. Subsequent observations three weeks later revealed several cleared areas near the nest, including a broad apron around the circumference of the nest. The dimensions of two of the prominently cleared areas were $60 \times 16 \mathrm{~cm}(1 \times \mathrm{w})$ and $47 \times 30 \mathrm{~cm}$. All colonies displayed distinctly visible cleared areas of variable shape (range 50-70 cm long, $15-85 \mathrm{~cm}$ wide), and number (2-5). Cleared areas were non-overlapping on opposite sides of the nest.

\subsubsection{Brood comb}

In some nests, the brood comb was located very near the nest entrance, leaving little space between the external opening and the brood 
chamber. Other nests had entrance tunnels extending to $25 \mathrm{~cm}$ in length leading into the brood cavity. The shape of the brood comb was more or less circular, often taking on the shape of the nest canopy (see Cameron et al., 1999). In all of the dissected nests $(n=9)$, the active brood cells were constructed on top of old, decayed cells, as noted by Olesen (1989). Some nests had several layers of old brood cells. The layers of these cells were usually attached to one another. Beneath the new brood and layers of old cells there was often a layer of complete (uncut) leaves or sticks. A lining of uncut leaves was often constructed around the internal circumference of the canopy as well. The brood comb was anchored inside the nest cavity with rootlets and frequently with small roots growing from saplings protruding through the top of the canopy. Waxen connectives also served to attach the comb to the walls of the cavity. Brood cell layers were attached vertically with waxen connectives. Fungus was not present on the floor or brood comb of healthy, active nests.

Only two of the nine dissected nests (22\%) had a wax envelope in or around the brood chamber. These did not completely encompass the brood comb, but were remnants of a wax covering. Tall, dark waxen honey pots (silos) constructed by the bees explicitly for honey storage were arranged around the periphery of the brood comb. These were approximately $1.5 \mathrm{~cm}^{3}$ in size. They were sometimes full and sealed but many were open and not full. The number of honey silos ranged from 6-72 among the observed nests. Some silos were used for pollen storage but these were few in number (many fewer than those with honey) and placed both among the brood cells and peripherally around the comb.

Pollen pockets were attached to larval clusters for feeding larvae. This species is thus a 'pocket maker' (Sladen, 1912), which is consistent with observations by Dias (1958) and with knowledge of other Fervidobombus species (Plath, 1934; Sakagami et al., 1967; Sakagami, 1976). As in most Bombus, egg cells composed of a mixture of wax and pollen are constructed atop the pupal cocoons and waxen casings of the late-stage larvae. All colonies had a single adult queen, but only one colony (TC1) possessed reproductive brood.

\subsection{Temperature and humidity}

Mean internal nest temperature was $30.1{ }^{\circ} \mathrm{C}$ $\left(\mathrm{n}=4\right.$ nests, range $=26.5-33^{\circ} \mathrm{C}$. Internal temperature remained approximately $4.5^{\circ} \mathrm{C}$ warmer than external ambient temperature ( $\mathrm{n}=4$ nests; $P=0.003$ ), although internal temperature was not more constant than external temperature $(P=0.858)$. External relative humidity was between $88-100 \%$, regardless of time of day or location of different nests. A malfunction in the RH data logger precluded collection of internal RH measurements. Yet despite the heavy rains and high external $\mathrm{RH}$, the internal nest environment was entirely dry.

\section{DISCUSSION}

The tropical wet forests of the Amazon Basin accumulate yearly precipitation levels between 2000 and $3000 \mathrm{~mm}$, with no month receiving less than $100 \mathrm{~mm}$ (Salati and Vose, 1984; Meggars, 1988, as cited in Kricher, 1997; Kricher, 1997). Relative humidity is never less than $90 \%$ at ground level and temperatures range from $29-32{ }^{\circ} \mathrm{C}$. During the rainy season, daily torrential downpours last for several hours, with rain often falling throughout the day. As we have shown, the tightly woven thatching enveloping a $B$. transversalis colony serves as an effective waterproof barrier in these wet tropical forests. The brood chamber beneath the canopy of a healthy colony is entirely dry and fungus-free despite daily deluges of rain and near to maximum RH levels. Unhealthy colonies have disheveled canopies that allow moisture to penetrate the brood chamber, hence they are riddled with moisture and fungus. Evidence from a separate study (Ramírez and Cameron, 2003) shows that the nest canopy also acts as a first-line impediment to attack by predatory raids of army ants (Eciton) as they scour the forest floor in search of small prey. Ants can only enter the nest through the single opening at the entrance, where the ants appear to be blocked either by the physical presence of the guard bees and/or chemical repellants.

The canopy and associated leaf-cutting activity is entirely unique to the Amazonian 
bumble bee. Though other species of Fervidobombus construct colonies on the ground surface, nesting in preexisting clumps of grass and occasionally in cavities beneath the surface (Michener and Laberge, 1954; Sakagami, 1976; Cameron and Jost, 1998; T. Whidden pers. comm.), B. transversalis is the only bumble bee we know that sends out groups of workers to cut leaf fragments from the ground litter and transport them to the nest site for the building and maintenance of an elaborate protective canopy. Cooperation among the construction workers is visible in the tandem sweeping of leaves during their transferal from the forest floor to the canopy. As leaves are cut and removed from selected areas, the forest floor is locally cleared of vegetation. These cleared areas are visible in the form of fringes around the circumference of the nest or as bare patches on the periphery of the nest. Occasionally the cleared areas take the form of linear trails leading away from the nest (Cameron and Whitfield, 1996; Cameron et al., 1999). Given that leaves fall from the surrounding trees at a more or less constant rate, it is clear that at least some of these cleared areas are actively maintained. Marked guard bees frequently patrol these areas, walking to and from the nest, and accidental litter is removed (Cameron and Whitfield, 1996). Further observations are needed to determine whether the cleared areas or trails have a function beyond supplying the colony with a ready supply of leaves.

With regard to the physical features we measured across nest sites, the data suggest that no striking topographical features are being selected (e.g., narrow range of ground slopes or directional aspects), other than their location on terra firme, which has already been reported (Dias, 1958; Olesen, 1989; Cameron et al., 1999). Nor do any of the measured physical variables show statistically significant correlations with one another (e.g., degree of ground slope associated with a given aspect or direction). However, if we exclude the four Yasuní nests found outside of the old growth forest reserve zone (Y1, Y2, Y4 and Y5, Tab. II, located in hilly areas that had been logged), then the mean \pm SD of the slopes is greatly reduced $\left(6.4^{\circ} \pm 2.8^{\circ}\right.$ vs. $11.4^{\circ} \pm 8.9^{\circ}$ if latter nests included). These nests are definitely outliers relative to the slopes on which the other nests were found (mean slope of outlier nests alone $=21.5^{\circ} \pm 8.2^{\circ}$ ). In fact, most nests were not constructed on steep slopes in spite of considerable topographical variation in the forests of all of our study regions. A fuller survey and statistical analysis of potential slopes available to the bees relative to those they selected (not an easy study) would be required to draw any firm conclusions about slope choice.

There are notable characteristics of the vegetation found in conjunction with $B$. transversalis nests, including the presence of saplings and small tree roots around which nests are constructed. These provide structural support and help to anchor the nest and brood cells firmly to the ground. About one-third of the nests were built within buttresses of large trees, offering structural support and possible additional protection against the heavy rains. The saplings also provide shade, which is augmented by additional layers of broad-leaved rain forest shrubs and trees overhanging the nest. Queens select nest sites that differ broadly in exposure to sun and shade, although they avoid sites in full sun (rank 1) or full shade (rank 5). However, a more direct measure of the actual amount of sun hitting the nest throughout the day (e.g., use of a terrestrial light sensor and datalogger), as compared to that above the canopy and at randomly selected positions in the forest, might be more revealing about sun/shade preference.

It is clear that nest-founding queens are at minimum selecting sites that do not flood and which provide structural support. Furthermore, internal nest environment functions independently of ambient conditions, maintained at lower humidity and temperature. This may be mostly due to the insulating features of the nest canopy, though fanning workers probably play a role in reducing both environmental components. Fanning at the nest entrance is particularly active during the part of the day when the sun strikes the nest directly.

\section{Seasonal colonies/ perennial nests}

In temperate areas, bumble bee colonies rarely survive more than one year (Sakagami, 1976). Colonies break up in the fall and the fertilized gynes overwinter to emerge in the 
spring and establish a new colony. There is typically only one queen per colony. In tropical regions, some species are active throughout the year and a distinctly seasonal establishment of new colonies is not prevalent. For instance, many B. atratus colonies persist for more than one year, and are considered to be perennial (Moure and Sakagami, 1962). Dias (1958) states that $B$. transversalis has a seasonal life cycle, active only for a few months during the dry season, and succumbs within the year. In contrast, Moure and Sakagami (1962) reported that $B$. transversalis workers can be collected in most months, although reproductives were not taken during the wetter months. Early and mid stages of colony development were common in mid to late wet season in our study. The single late stage colony, with reproductive brood (TC1, Tab. II) was found during the dry season. In a separate study of recruitment behavior, Dornhaus and Cameron (2003) collected two B. transversalis colonies at the end of the dry season; both were in late reproductive phase, with many new gynes and males. From these combined observations during different seasons of the year, we suggest that $B$. transversalis colony development in the Amazon Basin is synchronized with the seasonal wet/dry cycles: colonies are established during the wet season and complete their reproductive cycle during the dry season (additional observations by T. Roulston, pers. comm.). Observations on colony cycle, in combination with a number of our observations of nest age and structure, suggest that colonies (adults and brood cells) of $B$. transversalis may be seasonal, while the nest structure itself (no adults and brood) may be perennial. Local inhabitants at several study sites claimed to have seen $B$. transversalis nests persisting for several years. The A4 nest from Peru, with a very large canopy (Tab. II), was reliably documented to be at least 3 years old. Importantly, that nest contained a young queen (determined by lack of wing wear and bright pile color) with a small brood comb. This was quite striking given the outsized canopy dimensions of the nest. The nest also contained fresh brood comb with three layers of old comb beneath it, as did numerous other nests we dissected. These preliminary findings suggest that at least some of the nest structures survive beyond one year, and may be reused, while the colonies themselves begin anew each year with a fresh foundress. Reuse of an old nest is unusual in Bombus, whose seasonal colonies attract high scavenger and parasite loads as the colony senesces (Whitfield and Cameron, 1993; Whitfield et al., 2001). However, a $B$. transversalis nest represents a large investment, and if there is a hiatus between the termination of one colony cycle and the beginning of a new colony, scavengers and parasites may die off. Our understanding of the relationship among nest size, longevity and reuse is still fragmentary.

\section{ACKNOWLEDGMENTS}

We are indebted to the members of the Bee Team (D. Cole, S. Messinger, S. Ramírez, K. Roesch), and to Jim Whitfield for invaluable assistance in the field. N. Winchester and R. Ring provided support and assistance. We thank the staff at Amacayacu National Park in Colombia for general assistance; F. Fernandez (Humboldt Institute, Colombia) and D. Romo (Tiputini Biodiversity Station, Ecuador) for assistance with collection permits; F. Coster and G. Onore for assistance with accommodations at Yasuní Station; J. Guerra and C. Klein for assistance at Tiputini Biodiversity Station; and E. Shlenke for assistance at Tambopata Jungle Lodge. The research was supported by a National Science Foundation grant (IBN-9973447) to S.A.C.

Résumé - Construction et architecture du nid d'un bourdon (Hymenoptera, Apidae) d'Amazonie. Nous avons étudié en Amazonie le site de nidification et les caractéristiques architecturales du nid du bourdon Bombus transversalis. La répartition naturelle de ce bourdon se situe dans les forêts pluviales tropicales des plaines du bassin amazonien (Lievano et al., 1991; Cameron et al., 1999) (Tab. I), alors que la plupart des bourdons se rencontrent dans les régions montagneuses des zones tempérées et froides de l'hémisphère Nord (Plowright and Laverty, 1984 ; Labougle, 1990). $\mathrm{Au}$ total 16 colonies sauvages de $B$. transversalis ont été étudiées dans quatre pays (Colombie, Brésil, Equateur et Pérou) de mai à août 2000. Les colonies se signalent par une couverture étanche composée de petits fragments de feuilles, qui sont coupés et transportés sur le site de nidification par un groupe d'ouvrières spécialisées temporairement dans la construction du nid. Le tableau II donne les caractéristiques des nids. Les colonies sont saisonnières et leur développement semble lié au cycle saison sèche/saison humide de la région. La structure du 
nid peut néanmoins durer plus d'un an et être réutilisée par de nouvelles reines.

Bombus / nidification / adaptation / cycle de développement / comportement de découpe des feuilles / Apidae

Zusammenfassung - Anlage und Architektur von Nestern einer Hummel im Amazonasgebiet (Hymenoptera: Apidae). Nistplatz und architektonische Eigenschaften von Nestern der Hummel Bombus transversalis im Gebiet des Amazonas wurden untersucht. Die natürlicheVerbreitung von B. transversalis liegt im tropischen Tiefland Regenwald des Amazonas Beckens (Lievano et al., 1991; Cameron et al., 1999) (Tab. I). Die meisten Hummelarten kommen im Hochland von gemäßigten und in kalten Regionen in der nördlichen Hemisphäre vor (Plowright and Laverty, 1984; Labougle, 1990). Insgesamt wurden 16 natürlich nistende Völker von $B$. transversalis in 4 Ländern (Colombien, Brasilien, Ecuador und Peru) zwischen Mai und August 2000 untersucht. Die Nester zeichnen sich durch eine wasserdichte Überdachung aus kleinen Blattstücken aus, die von einer Gruppe von Arbeiterinnen, die sich zeitweise auf den Nestbau spezialisierten, zerteilt und zum Nest getragen werden. Die Völker treten saisonal auf und die Entwicklung scheint an den Regen/Trocken Zyklus der Region angepaßt zu sein. Allerdings kann ein Nest länger als ein Jahr intakt bleiben und von jungen Königinnen erneut benutzt werden.

Corbiculate Bienen / Neotropen / Blattschneideverhalten / Anpassung / Lebenszyklus des Volks

\section{REFERENCES}

Burks B.D. (1951) Tribe Bombini, in: Muesebeck C.F.W., Krombien K.V., Townes H.K. (Eds.), Hymenoptera of America north of Mexico, synoptic catalog. (Agric. Monogr.), Washington, DC, pp. 1247-1255.

Cameron S.A., Jost M.C. (1998) Mediators of dominance and reproductive success among queens in the cyclically polygynous Neotropical bumble bee Bombus atratus Franklin, Insectes Soc. 45, 135-149.

Cameron S.A., Whitfield J.B. (1996) Use of walking trails by bees, Nature 379, 125.

Cameron S.A., Whitfield J.B., Cohen M., Thorp N. (1999) Novel use of walking trails by the Amazonian bumble bee, Bombus transversalis (Hymenoptera: Apidae), in: Byers G.W., Hagen R.H., Brooks R.W. (Eds.), Entomological contributions in memory of Byron A. Alexander, Univ. Kans. Nat. Hist. Mus. Spec. Publ. 24, pp. 187-193.
Cameron S.A., Williams P.H. (2003) Phylogeny of bumble bees in the New World subgenus Fervidobombus (Hymenoptera: Apidae): congruence of molecular and morphological data, Mol. Phylogenet. Evol. 28, in press.

Dias D. (1958) Contribuição para o conhecimento da bionomia de Bombus incarum Franklin da Amazônia (Hymenóptera: Bombidae), Rev. Bras. Entomol. 8, 1-20.

Dias D. (1960) Nota sobre um ninho de Bombus construido acima do chao. (Hymenóptera, Apoidea), Rev. Bras. Entomol. 9, 151-156.

Dornhaus A., Cameron S. (2003) A scientific note on food alert in Bombus transversalis, Apidologie 34, 87-88.

Janzen D.H. (1971) The ecological significance of an arboreal nest of Bombus pullatus in Costa Rica, J. Kans. Entomol. Soc. 44, 210-216.

Kricher J. (1997) A Neotropical companion: an introduction to the animals, plants, and ecosystems of the New World tropics, Princeton University Press, Princeton.

Krombein K.V. (1967) Bombus, in: Krombien K.V., Burks B.D. (Eds.), Hymenoptera of America north of Mexico, synoptic catalog. (Agr. Monogr.), Second supplement, Washington, DC, pp. 515-520.

Labougle J.M. (1990) Bombus of Mexico and Central America, Univ. Kans. Sci. Bull. 54, 35-73.

Lievano A., Ospina R., Nates G. (1991) Distribucion altitudinal del genero Bombus en Colombia (Hymenoptera: Apidae), Invertebrados 4, 541550.

Michener C.D. (1974). The social behavior of the bees: a comparative study, Harvard University Press, Massachusetts.

Michener C.D. (2000). The bees of the world, John Hopkins University Press, Baltimore, Maryland.

Michener C.D., LaBerge W.E. (1954) A large Bombus nest from Mexico, Psyche 61, 63-67.

Milliron H.E. (1961) Notes on the nesting of Bombus morio (Swederus) (Hymenoptera, Apidae), Can. Entomol. 93, 1017-1019.

Moure J.S., Sakagami S.F. (1962) As mamangabas sociais do Brasil (Bombus Latreille) (Hymenoptera, Apoidea), Stud. Entomol. 5, 65-194.

Olesen J.M. (1989) Behavior and nest structure of the Amazonian Bombus transversalis in Ecuador, J. Trop. Ecol. 5, 243-246.

Plath O.E. (1934) Bumblebees and their ways, Macmillan Company, NY.

Plowright P.C., Laverty T.M. (1984) The ecology and sociobiology of bumble bees, Annu. Rev. Entomol. 29, 175-199.

Ramírez S., Cameron S.A. (2003) Army ant attacks by Eciton hamatum and E. rapax on nests of the Amazonian bumble bee, Bombus transversalis (Hymenoptera: Apidae), J. Kans. Entomol. Soc. (in press)

Roig-Alsina A., Michener C.D. (1993) Studies of the phylogeny and classification of long-tongued bees, Univ. Kans. Sci. Bull. 55, 123-162. 
Sakagami S.F. (1976) Specific differences in the bionomic characters of bumblebees: a comparative review, J. Fac. Sci., Hokkaido Univ. Series VI, Zool. 20, 390-447.

Sakagami S.F., Akahira Y., Zucchi R. (1967) Nest architecture and brood development in a neotropical bumblebee Bombus atratus, Insectes Soc. 14, 389-414.

Salati E., Vose P.B. (1984) Amazon basin: a system in equilibrium, Science 225, 129-138.

SAS Institute Incorporated (2000) JMP IN 4.0.3 (Academic), SAS Institute Incorporated, Duxbury Press.

SPSS Incorporated (2000) SPSS Advanced Statistics 10.0., SPSS Incorporated, Chicago.

Sladen F.W.L. (1912) The humble-bee, its life-history and how to domesticate it, Macmillan and Company, London.

Whitfield J.B., Cameron S.A. (1993) Comparative notes on hymenopteran parasitoids in bumble bee and honey bee colonies (Hymenoptera: Apidae) reared adjacently, Entomol. News 104, 240-248.

Whitfield J.B., Cameron S.A., Ramírez S., Roesch K., Messinger S., Taylor M., Cole D. (2001) Review of the Apanteles species (Hymenoptera: Braconidae) attacking Lepidoptera in Bombus (Fervidobombus) (Hymenoptera: Apidae) colonies in the New World, with description of a new species from South America, Ann. Entomol. Soc. Am. 94, 851-857.

Williams P.H. (1998) An annotated checklist of bumble bees with an analysis of patterns of description (Hymenoptera: Apidae, Bombini), Bull. Br. Mus. (Nat. Hist.), Entomology 67, 79-152.

Zucchi R. (1973) Aspecto bionomics de Exomalopsis aureopilosa e Bombus atratus incluindo consideraçòes sobre a evolução do compartamento social (Hymenoptera, Apoidea), Dissertation thesis viii+172p., Faculdade de Filosofia, Ciencias e Letras de Ribeirao Preto, Ribeirão Preto, SP, Brasil. 